Editorial Board

Advisor

Dr. Upendra Gautam Nepal

Editor-in-Chief

Upendra Dev Bhatta Nepal

Managing Editor

Bhai Raja Manandhar

Associate Editors

Rajendra P. Thanju

Nepal

Salil Devkota

Nepal

Dr. Rabin Shrestha

Nepal

Dr. Amimul Ahsan

Sr. Lecturer

Dept. of Civil Engineering

(University Putra Malaysia)

Team Member

Nepal

Dr. David J. Molden

DG, ICIMOD (International Centre for

Integrated Mountain Development)

Prof. Dr. Kiran K. Bhattarai

(Environment Specialist)

Dr. Shree Govind Shah

(Environment Specialist)

Prof. Dr. Ramesh K. Maskey

(Head, Civil and Geomatics Engineering

Dept., Kathmandu University)

Prof. Dr. Ram Manohar Shrestha

(Emeritus Prof., AIT, Bangkok, Thailand)

Norway

Dr. Krishna Kant Panthi

(Asso. Prof., NTNU)

China

Prof. Dr. Liu Heng

Director General,

(International Centre of Small Hydropower, Hanghzou)

USA

John Garcia

(Principal : GANDA)

India

Dr. MP Sharma

(Asso. Prof., AHEC, IIT, Roorkee)

Dr. Vishnu Prasad

(Prof., Dept of Civil Engineering, MANIT, Bhopal)

\section{Light at the end of Tunnel - expectations of a bright future}

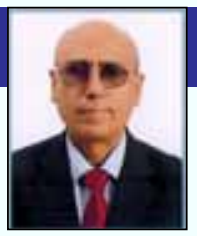

$T_{1}$ his winter in Kathmandu has not been that severe compared to last year. Thanks to the end of power cut by Nepal Electricity Authority and partially to global warming! Are we in a position to see the day light at the end of the tunnel? Should we expect a bright future for all Nepalese in general and the Kathmanduites in particular?

Several hydropower projects are under construction both in public and private sectors for the last so many years and some of them are nearing completion. Among such projects Upper Tamakoshi 456 MW (Annual Energy 2013 GWh), Rasuwagadhi 111 MW (Annual Energy 613.875 GWh), Upper Trishuli 3A, Mid Bhotekoshi 102 MW (Annual Energy 542.2 GWh), Chameliya $30 \mathrm{MW}$ (Annual Energy 184.21 GWh) are the prominent ones. If given a push, these projects can be commissioned within one to two years. Otherwise, there is a risk of cost overrun and worse the investment cost could turn into a sunk cost. The usual response from the authorities on the progress of such projects is earthquake of 2015, contractor not being responsible, delay in environmental clearances and the soaring expectations and demands of local people and so on and so forth.

The commoner on the street knows that reliable and cost effective power supply is essential for domestic, commercial and industrial purposes. Not only in the capital city and other towns, even rural areas need power supply as soon as possible. Last year's back breaking energy blockade and its aftershocks are not easily forgotten although peoples' memory is very short.

From energy security point of view, the generation, transmission and distribution projects that are nearing completion must be taken on a war footing and work must continue 24 hours a day seven days a week and 365 days a year! Let us apply common sense to the problems we are facing. The letter and spirit of the contract must be respected by both the owner and contractor. Since the real life situation is dynamic, the authorities must not hesitate in taking timely decision and it does not behoove the high officials to show the pretext of this or that kind. The lingering mentality of all concerned is sure to make hydropower development goal an ever elusive mirage.

If there is not adequate generation, transmission and distribution capacity in the country and the dreaded load shedding is reduced or eliminated by the huge imports, then such a situation is likely to induce lethargy in government and power bureaucracy at the same time draining the valuable financial resource from the country and therefore must not be encouraged unless absolutely essential for a short term.

Let us hope and pray that authorities listen and deliver the services to the people. With this kind of positive spirit, we are sure to see the light at the end of tunnel for a bright future.

This special issue on hydropower development has several articles from the prominent authors and HYDRO Nepal requests valuable comments/feedback from the readers.

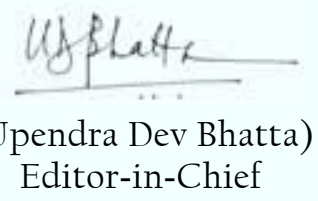

